\title{
Myocardial injury triggered by combination of emotional stress and carbon monoxide poisoning
}

\author{
Tatjana Miljkovićc, ${ }^{1,2}$ Aleksandra Milovančev ${ }^{1}$, Ilija Srdanović1,2, Maja Stefanović ${ }^{1,2}$, \\ Marija Bjelobrk ${ }^{1,2}$, Aleksandra Ilić1,2 \\ ${ }^{1}$ Institute of cardiovascular diseases of Vojvodina, Sremska Kamenica, Serbia, ${ }^{2}$ Faculty of Medicine, University of \\ Novi Sad, Novi Sad, Serbia
}

Abstract

\begin{abstract}
Introduction: Carbon monoxide (CO) is a leading cause of poisoning worldwide.Central nervous systems and the heart have the highest demand for oxygen and may be severely injured in CO poisoning. Case report: A patient was referred to the emergency department after exposure to $\mathrm{CO}$ and strong emotional stress. On admission she was comatose with elevated lactate 14,62 , metHgb $0,3 \%$ and carboxyhemoglobin $12,9 \%$. Electrocardiogram showed sinus rhythm, 100 beats/min, poor $\mathrm{R}$ wave progression with inverted T waves in V1-V3 leads, biphasic T waves in V5 and V6. Transthoracic echocardioography showed left ventricle with akinetic apex and all apical segments of the left ventricle with reduced systolic function. Cardiac troponin was significantly elevated; coronary angiography showed normal coronary arteries without culprit lesion. Takotsubo syndrome was diagnosed. She was treated with high flow oxygen on mechanical ventilation, antiplatelet, angiotenzinconvertase inhibitors, beta blockers and statin therapy with complete recovery. After one month ehocardiography showed left ventricle normal in size and function.

Conclusion: CO poisoning hasn't yet been described as a trigger for Takotsubo syndrome. We propose that two risk factors $\mathrm{CO}$ poisoning and stress by may have initiated a catecholamine surge and caused the development of this specific condition.
\end{abstract}

Keywords carbon monoxide poisoning, cardiotoxicity, takotsubo syndrome

\section{Introduction}

arbon monoxide $(\mathrm{CO})$ poisoning is the most frequent type of fatal poisoning all around the world ${ }^{1}$ and is considered as a major public health problem ${ }^{2}$. Natural gas heating systems may cause $\mathrm{CO}$ poisoning ${ }^{3}$. Carbon monoxide is produced by the incomplete combustion of carbon fuels, including inadequately ventilated heaters and car exhausts ${ }^{4}$. $\mathrm{CO}$ is an odourless, highly toxic gas and poisoning causes hypoxia, cell damage, and death ${ }^{5}$.

The most important mechanism of CO toxicity is tissue hypoxia ${ }^{1}$. The high affinity of carbon monoxide to bind to hemoglobin molecules (200 to 240 times that of oxygen) results in displacing the oxygen and generating carboxyhemoglobin, which is not able to release the oxygen to tissues and is thereby responsible for variable degrees of hypoxia ${ }^{6}$.

Those tissues with the highest demand for oxygen such as central nervous systems and heart are prone to injury in the acute and delayed clinical features ${ }^{7}$. Besides hypoxic damage, carbon monoxide produces myocardium injuries with cardiospecific mechanisms, mostly attributable to direct damage at cellular or subcellular level.
Exposure to $\mathrm{CO}$ is measured either directly from blood samples and expressed as a percentage of carboxyhaemoglobin or indirectly using the carbon monoxide in expired breath ${ }^{4}$.

$\mathrm{CO}$ induced cardiotoxicity has many clinical manifestations including arrhythmias ${ }^{8}$, left ventricular dysfunction, heart failure, myocardial infarction ${ }^{9}$ and pulmonary edema ${ }^{10}$.

Takotsubo syndrome is an acute and usually reversible heart failure syndrome ${ }^{11}$. It can be triggered by strong physical or emotional stress and is found commonly in postmenopausal women ${ }^{12}$. It is characterized by pathognomonic contraction patterns of the left ventricle (right ventricle may also be affected) ${ }^{12,13}$. Wall motion abnormality extends more than single epicardial coronary artery distribution and often results in circumferential dysfunction of the ventricular segments involved ${ }^{11}$. There are a number of shared factors between $\mathrm{CO}$-induced cardiotoxicity and takotsubo syndrome, although the clinical aspects are not completely identical ${ }^{14}$.

We here present a case of a 39-year-old woman who developed acute left ventricular dysfunction after carbon monoxide poisoning and emotional stress. 


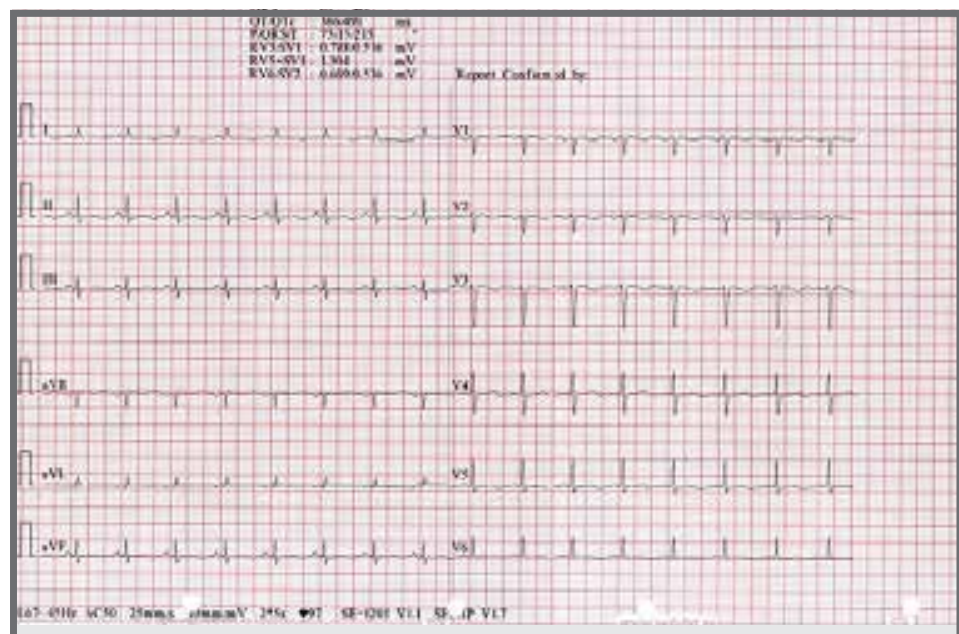

Figure 1. Electrocardiogram at the time of admission to hospital

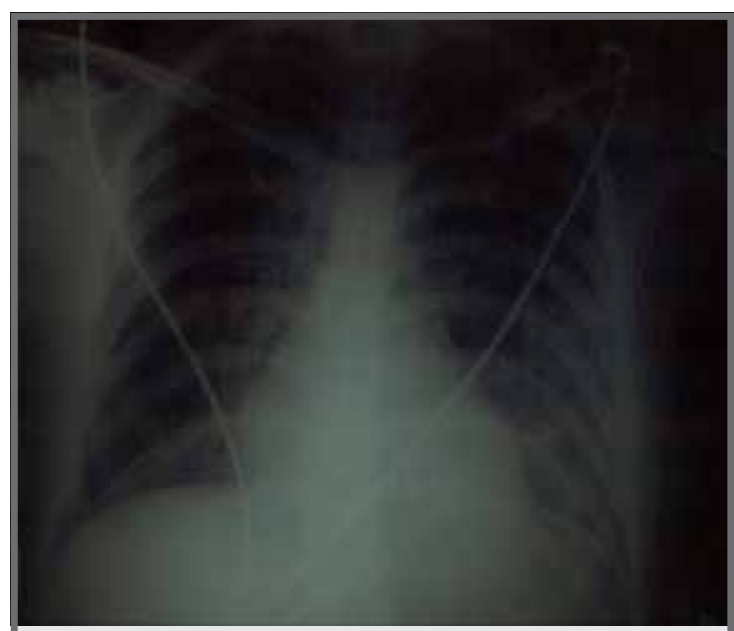

Figure 2. Chest radiograph at the time of carbon monoxide poisoning

\section{Case presentation}

A 39-year-old woman was referred to the emergency department due to suspicion of natural gas poisoning. That day she just came back from the funeral of closed cousin, went to shower, when her husband found her unconscious under the shower in the bathroom. The bathroom was without windows and they were using gasoline-powered water heater. On physical examination at admission, she was comatose, blood pressure of 140/100 $\mathrm{mmHg}$, heart rate was 110 beats/min and the respiration rate was 32 breaths per minute. She was intubated, ventilated and transferred to The Pulmonology intensive care unit. On admission to intensive pulmonology care unit her body temperature was $36.2^{\circ} \mathrm{C}$, blood pressure of 120/90 $\mathrm{mmHg}$, heart rate 106 beats/min. Initial laboratory blood gas analysis was as follows pO2 $67,9 \mathrm{mmHg}$, pCO2 29,9mmHg, lactate 14,62, metHgb 0,3\%, pH 7,04. Complete blood count WBC $2,4 \times 10^{9}$, Rbc $3,06 \times 10^{12}$, Hgb $97 \mathrm{~g} / \mathrm{l}$, Hct 0,28 , Plt $68 \times 10^{9}$; carboxyhemoglobin was $12,9 \%$. The markers of cardiac injury were elevated: Creatine kinase (CK) 2,83 $\mu \mathrm{kat} / \mathrm{l}(0.0-2.25)$, Creatine kinase-

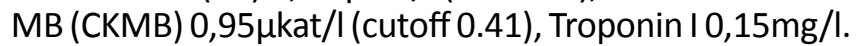
(cut off 0.01). Electrocardiogram showed sinus rhythm, 100 beats/min, poor $R$ wave progression with inverted $T$ waves in V1-V3 leads, biphasic T waves in V5 and V6 (Figure 1). Transthoracic echocardioography showed left ventricle normal in size with akinetic apex and all apical segments of the left ventricle with reduced systolic function. Ejection fraction was estimated at $45 \%$. Chest radiograph showed diffuse bilateral inhomogen infiltrates (Figure 2). Computed tomography of the head was normal. The patient was treated with high flow oxygen in Synchronized Intermittent-Mandatory Ventilation (SIMV) mode of mechanical ventilation. One day after carboxyhemoglobin was 2,6\%. and she was extubated. The markers of cardiac injury increased Creatine kinase (CK) $3.4 \mu \mathrm{kat} / \mathrm{I}(0.0-2.25)$, Creatine kinase-MB (CKMB) 0,38 $\mu$ kat/I (cutoff 0.41), Troponin $10,42 \mathrm{mg} / \mathrm{l}$. (cut off 0.01 ) and she was transferred to The Clinic for cardiology for further diagnostic follow up. Coronary angiography showed normal coronary blood vessels. Regarding to all data, Takotsubo syndrome was diagnosed. She was treated with antiplatelet, angiotenzin convertase inhibitors, beta blockers and statin therapy.

She was discharged in good condition, with carboxyhemoglobin $2 \%$. After one month ehocardiography showed left ventricle normal in size and function with preserved systolic function without wall motion abnormalities (Figure 3). Her treatment was continued with peroral antiplatlet therapy (acetil salicil acid) and beta

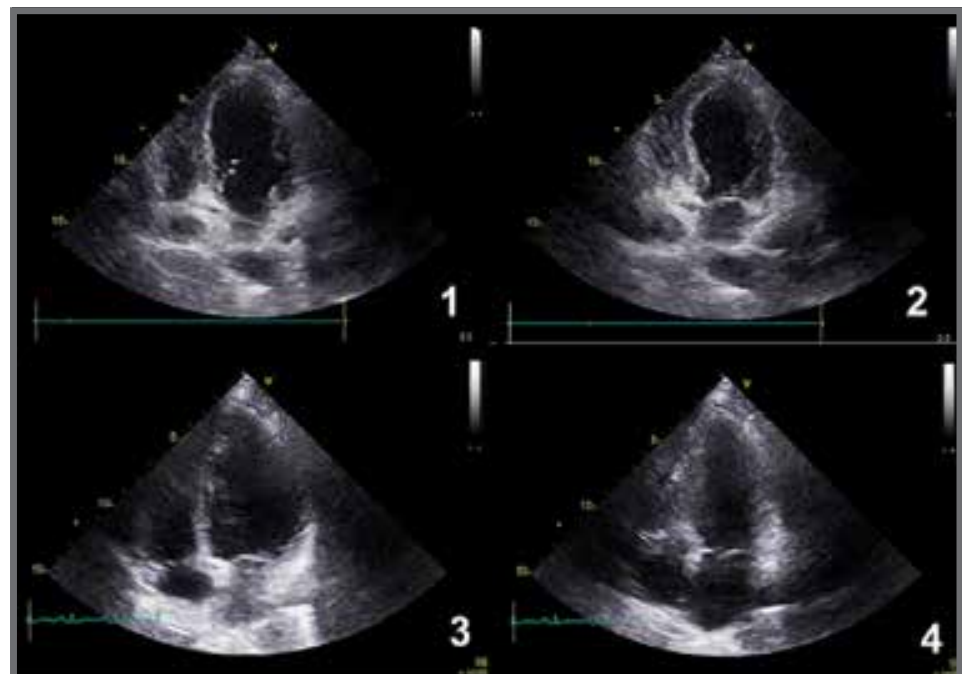

Figure 3. Apical echocardiography images of left ventricle 
blocker for a year with complete recovery.

\section{Discusion}

We here report a case of a 39 year old woman who developed acute left ventricular dysfunction with same echocardiographic regional wall motion abnormality pattern as in Takotsubo syndrome after exposure to CO and emotional stress.

CO induced cardiotoxicity occurs aproximatly in $1 / 3$ of moderate to severe CO poisoning cases ${ }^{15}$. Different clinical manifestations with diverse outcomes, even under similar exposure conditions ${ }^{16}$ can be seen. The clinical features and the pathophysiology of $\mathrm{CO}$ induced cardiac injury are not completely understood and several additional mechanisms were proposed. The cardiovascular effects induced by $\mathrm{CO}$ poisoning may be due to decreased cardiac output caused by cellular hypoxia, binding of carbon monoxide with myoglobin, and diminished oxygen releas $\mathrm{e}^{17}$. Ismail et el. found a link between $\mathrm{CO}$ exposures and oxidative stress as a possible mechanisms of $\mathrm{CO}$ induced cardio-toxicity. When $\mathrm{CO}$ binds to cytochrome oxidase in the mitochondria, the electron-transport chain and consequent ATP production are interrupted, which result in anaerobic respiration and formation of lactate and free radicals. Other effects, such as relaxation of vessel smooth muscles, inflammation, and thrombotic tendency, contribute to further injury ${ }^{18-20}$. Other additional mechanisms of cardiovascular toxicity may be reperfusion injury, and disruption of CO's physical functions ${ }^{21,8}$.

Cateholamin surge was suggested as a most probable mechanism of $\mathrm{CO}$ induced cardiomyopathy (CMP) which results from acute $\mathrm{CO}$ poisoning ${ }^{22}$. Postmortem catecholamine levels of pericardial and cerebrospinal fluids were high in CO poisoned patients ${ }^{23,24}$. Catecholamine level was found to be elevated also in Takotsubo syndrome ${ }^{25}$.

Cha et all ${ }^{22}$ investigated the early incidence of $\mathrm{CO}$ induced cardiomyopathy and its patterns and found that patients with $\mathrm{CO}$ poisoning and myocardial injury experienced cardiomyopathy, including reversible global, regional wall motion abnormality and a Takotsubo-like pattern ${ }^{22}$.

Younger patients were more prone to global left ventricular dysfunction while older ones with more risk factors for coronary artery disease (CAD) had regional wall motion abnormality. Several authors reported case reports with the description of cardiovascular manifestations of CO poisoning but none didn't develop takotsubo like wall motion abnormality. Colvin end Stearnes documented ECG changes after CO poisoning 26,27 . Myocardial infarction has been reported in patients with underlying $C A D^{28}$ and in patient without preexisting $C A D^{29}$.

Lee et $\mathrm{al}^{7}$ investigated $\mathrm{CO}$ toxicity on large scale database $(\mathrm{N}=8381)$ and found that $\mathrm{CO}$ poisoning is associated with higher overall risk of subsequent development of arrhythmia and CAD, but no significant correlation was found between $\mathrm{CO}$ poisoning and development of chronic heart failure ${ }^{7}$.

Jung et al investegated cardiotoxicity in Six hundred and twenty-six patients with $\mathrm{CO}$ poisoning and found that $\mathrm{CO}$ induced CMP occured in $3 \%$ of $\mathrm{CO}$ poisoned patients. 6 patients had echocardiographic caracteristics that resembeled Takotsubo CMP and two resembeled reverse Takotsubo $\mathrm{CMP}^{14}$.

There are several common factors between CO-induced CMP and takotsubo CMP, although the clinical features are not entirely the same.

In the Takotsubo syndrome there are a lot of unknowns in the etiology and pathogenesis that lead to this type of transient myocardial damage. The most common cause of Takotsubo syndrome is emotional stress, but the physical stress is may also cause this form of this cardiomyopathy ${ }^{30}$. Considering the common factors between the CO-induced CMP and takotsubo syndrome, catecholamine surge might play a central role in the development of CO-induced CMP. Less commonly, the occurrence of Takotsubo syndrome is a consequence of a combination of various causes. In our case the involvement of a catecholamine mediated mechanism caused by $\mathrm{CO}$ poisoning and stress might caused this left ventricular dysfunction Takotsubo like syndrome in 39 year old woman. CO poisoning haven't yet been described as a trigger for Takotsubo syndrome.

We propose that acute catecholamine surge caused by $\mathrm{CO}$ poisoning and stress may have initiated the development of this specific condition.

In conclusion, cardiac injury is common and needs to be evaluated in every patient with CO poisoning. In the acute stage of $\mathrm{CO}$ poisoning prognosis is favorable if adequate treatment with $100 \%$ oxygen is initiated on time. Still, substantial risk for subsequent cardiovascular events is higher in this population and they should be closely observed.

\section{References}

1. Lippi G, Rastelli G, Meschi T, Borghi L, Cervellin G. Pathophysiology, clinics, diagnosis and treatment of heart involvement in carbon monoxide poisoning. Clin Biochem 2012; 45(16-17):1278-85.

2. Aslan S, Uzkeser M, Seven B, Gundogdu F, Acemoglu H, et al. The evaluation of myocardial damage in 83 young adults with carbon monoxide poisoning in the East Anatolia region in Turkey. Hum Exp Toxicol 2006; 25: 439-446.

3. US Consumer Product Safety Commission, Non-Fire Carbon Monoxide Deaths, 2011 Annual Estimate

4. Smollin C, Olson K. Carbon monoxide poisoning (acute). Clinical Evidence 2008;07:2013-2019.

5. Piantadosi CA. Carbon monoxide poisoning. Undersea Hyperb Med. 2004;31:167-177.

6. Blumenthal I. Carbon monoxide poisoning. J R Soc Med 2001 Jun;94(6):270-2.

7. Lee FY, Chen WK, Lin CL, Kao CHK. Carbon monoxide poisoning and subsequent cardiovascular disease risk: a nationwide population-based cohort study. Medicine 2015; 94 (10):1-8

8. Gandini C, Castoldi AF, Candura SM, Locatelli C, Butera R, Priori $\mathrm{S}$ et al. Carbon monoxide cardiotoxicity. J Toxicol Clin Toxicol 2001;39:35-44.

9. Choi IS. Carbon monoxide poisoning: Systemic manifestations and complications. J Korean Med Sci 2001; 16: 253-261.

10. McMeekin JD, Finegan BA. Reversible myocardial dysfunction following carbon monoxide poisoning. Can J Cardiol 1987; 3:118-121.

11. Lyon AR, Bossone E, Schneider B, Sechtem U, Citro R et al. Current state of knowledge on Takotsubo syndrome: a Position Statement from the Taskforce on Takotsubo Syndrome of the Heart Failure Association of the European Society of Cardiology. Eur J Heart Fail 2016; 18:8-27.

12. Kurisu S, Sato H, Kawagoe T, Ishihara M, Shimatani $Y$, Nishioka $\mathrm{K}$, et al. Tako-tsubo-like left ventricular dysfunction with ST- 
segment elevation: A novel cardiac syndrome mimicking acute myocardial infarction. Am Heart J 2002; 143: 448-455.

13. Redfors B, Shao Y, Omerovic E. Stress-induced cardiomyopathy (Takotsubo)--broken heart and mind? Vasc Health Risk Manag 2013; 9: 149-154.

14. Jung YS, Lee JS, Min YG, et al. Carbon Monoxide Induced Cardiomyopathy: Epidemiology, Clinical Characteristics, and Prognosis. Circulation Journal 2014; 78:1437-44.

15. Satran D, Henry CR, Adkinson C, Nicholson Cl et al. Cardiovascular Manifestations of Moderate to Severe Carbon Monoxide Poisoning. JACC 2005; 45( 9):1513-6.

16. Raub JA, Mathieu-Nolf M, Hampson NB, Thom SR. Carbon monoxide poisoning--a public health perspective. Toxicology 2000; 145:1-14

17. Ismail MM, El-Ghamry H, Shaker OG, Fawzi MM, Ibrahim SF. Some Biomarkers in Carbon Monoxide-Induced Cardiotoxicity. J Environ Anal Toxicol 2013; 3: 176.

18. Szponar J, Kolodziej M, Majewska M, et al. Myocardial injury in the course of carbon monoxide poisoning. Przegl Lek. 2012; 69:528-534.

19. Grant M, Clay B. Accidental carbon monoxide poisoning with severe cardiorespiratory compromise in 2 children. Am J Crit Care 2002;11:128-131.

20. Ryoo SM, Sohn CH, Kim HJ, et al. Intracardiac thrombus formation induced by carbon monoxide poisoning. Hum Exp Toxicol 2013;32:1193-1196.

21. Ferrari R. Metabolic disturbances during myocardial ischemia and reperfusion. Am J Cardiol 1995; 76: 17B - 24B.
22. Cha YS, Kim H, Hwang SO, Kim JY, Kim YK, Choi EH. Incidence and patterns of cardiomyopathy in carbon monoxide-poisoned patients with myocardial injury. Clin Toxicol 2016; 54(6): 481-487.

23. Ishikawa T, Quan L, Michiue T, Kawamoto O, Wang Q, Chen JH, et al. Postmortem catecholamine levels in pericardial and cerebrospinal fluids with regard to the cause of death in medicolegal autopsy.Forensic Sci Int 2013; 228: 52 - 60.

24. Zhu BL, Ishikawa T, Michiue T, Li DR, Zhao D, Quan L, et al. Postmortem serum catecholamine levels in relation to the cause of death. Forensic Sci Int 2007; 173: 122 - 129.

25. Lyon AR, Rees PSC, Prasad S, Wilson PAP, Harding SE. Stress (Takotsubo) cardiomyopathy-a novel pathophysiological hypothesis to explain catecholamine-induced acute myocardial stunning. Nature Reviews Cardiology 2008, 5.1: 22.

26. Colvin LT. Electrocardiographic changes in a case of severe carbon monoxide poisoning. Am Heart J 1928;3:484-8.

27. Stearns WH, Drinker CK, Shaughnessy TJ. The electrocardiographic changes found in 22 cases of carbon monoxide (illuminating gas) poisoning. Am Heart J 1938;15:434-47.

28. Varol E, Ozaydin M, Aslan SM, et al. A rare cause of myocardial infarction: acute carbon monoxide poisoning. Anadolu Kardiyol Derg 2007; 7: 320-30.

29. Mokaddem A, Sdiri W, Semli K, Darghouth B, Mahjoub H, Bachraouik, et al. A rare cause of myocardial infarction: carbon monoxide intoxication. Tunis Med 2004; 82: 320-3.

30. Ono R, Falcão LM. Takotsubo cardiomyopathy systematic review: Pathophysiologic process, clinical presentation and diagnostic approach to Takotsubo cardiomyopathy. Int J Cardiol 2016; 209: 196-205.

\section{Sažetak \\ Oštećenje miokarda uzrokovano kombinacijom emocionalnog stresa i trovanja ugljen monoksidom - prikaz slučaja}

Tatjana Miljković ${ }^{1,2}$, Aleksandra Milovančev ${ }^{1}$, Ilija Srdanović1,2, Maja Stefanović, ${ }^{1,2}$, Marija Bjelobrk ${ }^{1,2}$, Aleksandra Ilić1,2 ${ }^{1}$ Institut za kardiovaskularne bolesti Vojvodine, Sremska Kamenica, Srbija, ${ }^{2}$ Medicinski fakultet, Univerzitet u Novom Sadu, Novi Sad, Srbija

Uvod: Ugljen monoksid (CO) je vodeći uzrok trovanja širom sveta. Centralni nervni sistem i srce imaju najveće potrebe za kiseonikom i mogu biti teško oštećeni u trovanju CO.

Prikaz slučaja bolesnice starosti 39 godina koja je nakon snažnog emocionalnog stresa i trovanja CO upućena u Urgentni Centar. Pri inicijalnom pregledu ona je komatoznog stanja svesti, a u laboratorijskim vrednostima se registruju povišene vrednosti laktata (14.62), metHgb 0,3\% i karboksihemoglobina 12,9\%. U EKG-u registrovan sinusni ritam, srčane frekvencije 100/min, slab porast R talasa sa inverznim T talasima V1-V3 i bifaznim T talasima V5, V6. Transtorakalnom ehokardiografijom viđena je leva komora sa akinetičnim vrhom i svim apikalnim segmentima leve komore, snižene sistolne funkcije. Kardiospecifični enzimi su bili povišeni, urađena je koronarograija kojom se nađe uredan luminogram koronarnih krvnih sudova. Na osnovu svih parametara, postavljena je dijagnoza Takocubo sindroma. Lečena je visokim dozama kiseonika na mehaničkoj ventilaciji, oralnim preparatima acetilsalicilne kiseline, inhibitorima angiotezin konvertujućeg enzima, beta blokatorima i statinima uz potpuni oporavak. Kontrolnom ehokardiografijom, nakon mesec dana, opisuje se uredan nalaz.

Zaključak: Trovanje CO do sada nije opisano kao precipitirajući faktor za razvoj Takotsubo sindroma. Dva riziko faktora trovanje ugljen monoksidom i stres inicirala su buru kateholamina koja je mogla da pokrene razvoj ovog specifičnog sindroma.

Ključne reči: trovanje ugljen monoksidom, kardiotoksičnost, takotsubo sindrom 